\title{
Üniversite Mezunu Evli Bireylerin Evlilik Algıları Üzerine Metaforik Bir İnceleme
}

\author{
Dr. Durmuş ÜMMET* \\ Marmara Üniversitesi, Atatürk Eğitim Fakültesi, Eğitim Bilimleri Bölümü, \\ Kadıköy / İstanbul / Türkiye
}

\section{$\ddot{O} z$}

$\mathrm{Bu}$ araştırmanın temel amacı üniversite mezunu evli bireylerin evlilik kavramına ilişkin algılarının metafor (eğretileme) analizi yoluyla incelenmesidir. Araştırmada nitel araştırma yöntemleri kapsamında metafor analizi yapılmıştır. Araştırmanın çalışma grubu üniversite mezunu ve evli olan 57'si kadın 43'ü erkek olmak üzere toplam 100 kişiden oluşmaktadır. Veri toplama aracı olarak, katılımcıların evlilik kavramına ilişkin sâhip oldukları zihnî imgeleri (metaforları) belirlemek için "Evlilik ..... gibidir; çünkü ........" cümlesini tamamlamaları istenmiştir. Araştırmada elde edilen bulgulara göre, üniversite mezunu evli bireylerin evlilik kavramına ilişkin toplam 100 adet ve 47 farklı geçerli metafor ürettikleri görülmüştür. Bu metaforlar ortak özellikleri bakımından 6 farklı kavramsal kategori altında toplanmıştır. Katılımcıların evliliğe dâir geliştirdikleri metaforların büyük oranda olumlu içeriğe sâhip oldukları, kadınların erkeklere göre evlilikle ilgili algılarının daha olumlu olduğu ve benzer şekilde çocuk sâhibi olan bireylerin evliliğe ilişkin algılarının çocuk sâhibi olmayanlardan daha olumlu olduğu görülmüştür. Elde edilen bulgular benzer çalışmalar bağlamında tartışılarak çeşitli öneriler getirilmiştir.

\footnotetext{
* Sorumlu Yazar. Tel: +90 5052947907

E-posta: dummet@marmara.edu.tr

ORCID: 0000-0002-8318-9026 
Anahtar Kelimeler: Evlilik; Aile; Üniversite; Alg1; Metafor.

\title{
A Metaphoric Examination of Marriage Perception of Higher Educated Married Persons
}

\begin{abstract}
The aim of this study was to examine the perceptions of marriage concept of higher educated married persons through metaphor analysis. In this study, metaphor analysis was conducted in context of qualitative research methods. Sample group consisted of 100 persons who had higher education and married; 57 of them were women and 43 were men. The participants were asked to fill the sentence "Marriage is like......, because ....." to determine the metaphor related to marriage they had for data collection tool. According to the findings, the sample group produced 47 different valid metaphors in total of 100 . These metaphors were grouped under 6 different conceptual categories considering their common traits. The developed metaphors by the participants about marriage were substantially positive, women had more positive perception about marriage than men and similarly, persons who had children had more positive perception about marriage than who were childless. These findings were discussed in the context of similar studies and various recommendations were brought forward.
\end{abstract}

Keywords: Marriage; Family; Higher education; Perception; Metaphor.

\section{Extended Summary}

\section{Purpose}

Started with a marriage contract and maintained in a healthy way, a family institution makes possible many phenomena such as the persistence of human race and order of societies, for the new generations, acquiring basic national and moral values and raising in a healthy way in all aspects. Although marriage varies in different societies, basically, it is defined as a universal institution made up of interconnected systems and formed by two persons aiming a lasting relationship for constitution of family and human 
generation. The following questions were sought to be answered in this research:

1. What are the metaphors about marriage developed by higher educated, married persons within the scope of research?

2. Can the metaphors about marriage developed by participants be grouped under which conceptual categories in context of their common traits?

3. How do the metaphors differ from the gender of higher educated, married persons within the scope of research?

4. How do the metaphors differ from having children of higher educated, married persons within the scope of research?

\section{Method}

Being a descriptive research aiming to explain a phenomenon as it is, this research was a qualitative research with the purpose of examining the developed metaphors about marriage by higher educated married persons. The research was carried out with 57 women, 43 men, in total100 persons who had higher education and married in the frame of research. The data of the research was collected by asking participants to fill the sentence "Marriage is like......., because ......". The developed metaphors about marriage by participants were analyzed in three phases: 1. Phase: Coding and sorting, 2. Phase: Categorizing, 3. Phase: Testing reliability and validity.

\section{Results}

The married persons produced 47 different metaphors in total of 100 metaphors about marriage in the scope of research. The frequency of themes created by according to the common traits of produced metaphors ranged as following: 29 of them were marriage as a phenomenon flavoring like food-beverages (29\%), 9 of them were marriage as a phenomenon making life difficult (9\%); 15 of them were marriage as a phenomenon making life easier (15\%); 9 of them were marriage as an illuminating phenomenon $(9 \%)$; 11 of them were marriage as a productive phenomenon (11\%) and 27 of them were marriage as a changeable phenomenon (27\%). The participant ascribed positive meanings to 76 of 100 metaphors (76\%) and negative meanings to 24 of 100 metaphors (24\%). Examining the range of developed metaphors according to gender variable, women participants had more positive perceptions 
than men. Analyzing the metaphors according to having children or being childless variables, participants who had children developed more positive metaphors than other participants who did not have any children.

\section{Discussion}

A total of 76 of metaphors produced by participants had positive meaning (76\%) while 24 of them had negative meaning (24\%) out of 100. This finding showed that married persons had mostly positive perception about marriage. There is a first-hand research about this subject; in the study of examining university students' attitudes towards marriage and family, Bener and Günay (2013) stated that most of the youngsters reported positive attitudes towards these concepts. Ministry of Family and Social Politics, 2014; General Directorate of Family and Social Researches, 2008 and 2009; and TÜİK (Turkish Statistical Institute) 2011 data showed that divorce rate was higher among mostly high schools and their equivalents' graduates.

Although the findings signified that both genders had predominantly positive perceptions about marriage, when compared it was found that women had more positive perceptions about marriage than men. There were similar study findigs though not directly related to the subject: In her study conducted with women, Yalçın (2014) asserted that 53.3\% of women evaluated marriage as very good-good, $18.3 \%$ of women evaluated marriage as very bad-bad and $28.1 \%$ of them evaluated marriage as normal. The findings of Bener and Günay's study (2013) also showed that positive attitudes of women about marriage were significantly higher than those of men. In the study of Polat (2006), it was reported that men had less satisfaction from marriage and therefore, they had more tendency to cheat than women.

Whereas the findings showed that both persons who had children and who were childless had positive perceptions about marriage, when compared it was found that persons who had children had more positive perceptions about marriage. Findings of researches in literature indirectly support this finding. Türkaslan (2007) stated that divorce rate was higher among childless families according to the number of children and asserted that children were the factor that prevented divorce. Demirci, Günaydın, Doğan ve Aynacı, (2005) reported that divorce rate was higher among childless marriages. 


\section{Conclusion}

In conclusion, the perception of higher educated persons about marriage was found as positive in this study. Yet, the data of this qualitative research cannot be generalized. Regarded with limitedness, it can be suggested to be useful that the subject might be re-evaluated with qualitative and larger samples or with mixed method research design. Only gender and having or not having children variables were examined in this study. The future studies conducted with other variables that may affect the perception of marriage in addition to these variables are thought to contribute to the literature. Finally, some practices can be planned and carried out in the context of guidance and psychological counseling activities in schools with families and their children implying the importance of family life and marriage first upon their mental health.

\section{Giriș}

İnsan neslinin devamı, yeni nesillerin temel millî ve manevî değerleri kazanmaları ve her bakımdan sağlıklı bir şekilde büyümeleri, toplumların var olmaları ve düzeni gibi birçok olgu o toplumdaki bireylerin evlilik akdi ile başlatıp sürdürecekleri sağlıklı aile kurumu ile mümkündür. Sağlıklı evliliklerin dolayısıyla sağlıklı ailelerin toplumsal hayata olan olumlu yansımaları kadar bireyin hayat doyumu, iyi oluşu, yani psikolojik sağlığı için de olumlu etkileri bulunmaktadır (Haldford, Kelly ve Markman, 1997; Williams, 2003). Evlilik kavramı ve tanımının kültürden kültüre değiş̧en yönleri olmasına ragmen, evrensel yönleri de bulunmaktadır. Sosyolojik anlamda incelendiğinde, farklı şekillerde olsa da her toplumda evlilik olgusunun var olduğu görülmektedir (Kammeyer, 1990). Saxton (1982) evliliği, farklı toplumlarda değişik yapılar gösterebilen; ancak temelde aile kurmayı ve neslin devamını sağlayan iki insanın kalıcı bir birliktelik için bir araya gelerek kurdukları, birbirlerine ve çocuklarına karşı ortak sorumluluklarını yerine getirmeye söz verdikleri, birbirine bağlı sistemlerden oluşan evrensel bir kurum olarak tanımlamaktadır. Evlilik, ailenin oluşturulmasında ilk evre olarak kabûl edilir. Aile kavramını net bir şekilde anlayabilmek için evlilik kavramının temellerine inilmesi, evliliğin oluşturulması ve evlilik süreci gibi konuların incelenmesi önem arz etmektedir (Güçlü, 1998). Bu rasyonelden hareketle, öncelikle evlilik kavramı tanımlanmaya çalışılmıştır.

İlgili alan uzmanlarınca yapılan tanımlardan hareketle evlilik; tam ve 
sürekli bir hayat ortaklığı kurmak üzere, cinsiyetleri ayrı iki kişinin hukuken makbul ve geçerli bir şekilde birleşmesi, kurumlaşmış bir yol, bir ilişkiler sistemi, bir kadınla bir erkeği "karı-koca" olarak birbirine bağlayan, doğacak çocuklara belli bir statü sağlayan, toplumsal yönden "devletin" kontrol, hak ve yetkisi bulunan, yani yasal boyutları da olan, eşler arasında birliğin olduğu, üyeleri arasında açık ve güvenilir ilişkinin bulunduğu, bireylerin doğal olabildiği ve kişisel farklılıkların yaşanabildiği, etkili bir iletişimin var olduğu, üyelerin maddî ve manevî ihtiyaçlarının giderilebildiği, yakınlık, kızgınlı ve cinsellikle ilgili duyguların yaşanabildiği bir sistemler bütünü, kısacası iki kişi arasındaki yakın ilişkinin meydana getirdiği bir birlikteliktir (Akıntürk, 1996; Jacobson ve Gurman, 1995; Hansen ve L'Abate, 1982; Özgüven, 2001). Bu evlilik birlikteliği çocukların dünyaya gelmesi ile aile kurumuna dönüşmektedir. Aile kan bağıyla kurulan asil bir kurumdur. Aile toplumun çekirdeği ve temel birimi, aynı zamanda en eski ve evrensel bir kurumudur. Aile nüfusu yenileme, millî kültürü nesilden nesle taşıma, çocukları sosyalleştirme, ekonomik, biyolojik ve psikolojik tatmin fonksiyonlarının yerine getirildiği bir müessesedir. Ayrıca aile ortamında psikolojik görevler bulunmaktadır. Bu görevler aile üyelerinin birbirlerine karşı duygusal bir bağ kurmalarını ve geliştirmelerini sağlar. Bu psikolojik görevler yerine getirilemediğinde, aile içindeki her birey birçok rahatsızlı̆̆ bir arada yaşar. Bireyin rahatsızlığ 1 , aslında içinde yaşadığı rahatsız bir ailenin ve kötü işleyen bir aile etkileşiminin belirtisidir (Erkal, 1997; Hojat, Shapurizan, Foroughi, Nayerahmadi, Farzaneh, Shafieyan ve Parsi, 2000; Karataş, 2002; Özabac1 ve Erkan, 2014; Şahinkaya, 1975; Ünal, 2013; Yavuz, 2003). Ortak kabuller çerçevesinde burada anlatımı yapılan aile olgusu ayrıca kültürden de kaçınılmaz olarak etkilenen bir kurumdur. Kaldı ki kültür, bir cemiyetin sâhip olduğu maddî ve manevî kıymetlerden, yani her çeşit bilgi, alâka, ihtiyaç, kıymet ölçüsü, genel görüş ve zihniyet ile her nev'i davranış şekillerinden oluşan bir bütün olarak tanımlanır (Turhan, 2015). Kendi kültürümüzde de aile tiplerinde epeyce farkl1l1klar olduğu için aile dinamikleri kendi yapısı içinde anlaşılabilir (Kağıtçıbaşı, 1990). Ancak hem bireyi hem de daha geniş bakış açısıyla toplumu doğrudan etkilediği genel bir kabul olan ailenin sağlıklı veya sağlıksız oluşunda yapılan evliliklerin niteliğinin etkili olduğu düşünülmektedir. Öncelikle evliliğin muhtevasını bu çerçevede incelemek yararlı olacaktır.

Her evlilik kendi içinde olumlu ve olumsuz yaşantıları deneyimler; 
ancak genel olarak evliliklerin sağl1klı veya sağl1ksız olduğunu belirlemede ortak kabul gören bazı kıstaslar bulunmaktadır. Sağlıklı evlilikler genellikle; eşlerin birbirlerini birçok yönüyle tanıdığı, karş11ıklı olarak âit olma, sevgi, sayg1, cinsel doyum vb. duygu ihtiyaçlarını karşıladıkları, ortak ilgilerin bulunduğu, maddî ve manevî değerler bağlamında birbirini tamamlayıcı özelliklere sâhip oldukları, her iki tarafin da taşıdıkları farklılıkları hoşgörü ile karşıladıkları ve bu farklılıkları kendine benzetmeye çalışmadan kabul ettikleri evlilikler olarak tanımlanır. Sağlıksız evlilikler ise tersi bir bakış açısıyla; eşlerin birbirlerinde sahip oldukları özellikleri yeterince tanımadıkları veya diğerinin kendisinden farklı olan yönlerini değiştirmeye çalıştıkları, benzer yönlerinden çok farklı özelliklerin ön plâna çıktığı, "biz" duygusundan ziyade "ben" duygularının dikkate alındığı evlilikler olarak tanımlanır (Bilen, 1996; Nazlı, 2014; Özabacı ve Erkan, 2014; Saxton, 1982; Yalçın ve Hamamc1, 2012). Sağlıksız evliliklerin içinde yaşanan bu olumsuz durumlar kısa vadede yoğun çatışmaları beraberinde getirmektedir. $\mathrm{Bu}$ çatışmalar giderilmediğinde ise bahsedilen olumsuzluklar kronik bir hâle dönüşür ve boşanma olgusu kaçınılmaz olur.

Boşanma eşler hayattayken evlilik ilişkisine mahkeme kararı ile yasal olarak son verilmesi olarak tanımlanmaktadır (Akıntürk, 1996). Özellikle son 30-40 yildır hem dünyada hem de ülkemizde boşanma oranlarında ciddi bir artış olduğu görülmektedir. Özellikle kent ailelerinde daha fazla görülen boşanma oranlarının artmasında; kadının iş hayatında daha fazla yer alması, teknolojik değişmelerdeki hız ve tüketim kültürünün toplumlarda yerleşmiş olması gibi sosyolojik nedenlerin yanı sıra boşanmış çiftlerle yapılan çalışmalar bize konuyla ilgili bazı bilgiler sunmaktadır. İlgili çalışmalar (Aile ve Sosyal Politikalar Bakanlığı, 2014; Başbakanlık Aile ve Sosyal Araştırmalar Genel Müdürlüğü, 2008, 2009; Çakır, 2011; Demirci ve ark., 2005; Ozankaya, 1979; Tatlilığlu ve Demirel, 2016; TÜíK, 2011) incelendiğinde; şiddetli geçimsizlik, zina, alkol-uyuşturucu kullanımı, ekonomik sorunlar, eşin ailesi ile ilgili zorluklar, cinsel problemler, kültürel uyumsuzluklar, şiddet, akıl hastalığı gibi sebepler boşanma nedenleri olarak sıralanmaktadır. Ayrıca bu araştırmalarda boşanan çiftler arasında lise mezunu olanların oranının en yüksek düzeyde olduğu bildirilmektedir. $\mathrm{Bu}$ oranlar bir bakıma eğitim düzeyi ile boşanma oranları arasındaki ilişkiyi göstermektedir. Boşanma olgusu bir yandan sosyolojik bir sorunken diğer yandan çocukların aynı zamanda çiftlerin ruh sağlığı ve davranış bozuklukları 
ile ilişkilerini ortaya koyan birçok araştırmanın (Aydın ve Baran, 2010; Öngider, 2013; Şentürk-Pehlivan, 2004; Şirvanl1-Özen, 1998; Türkaslan, 2007; Uzun, 2013) varlığından hareketle psikolojik olarak da ele alınması gereken bir konudur. Ancak evlilik, aile ve boşanma kavramları sosyolojik ve psikolojik bağlamlarda ele alınırken kendi kültürel bağlamı içinde değerlendirilmelidir. Kağıtçıbaşı (2007)'nın da belirttiği gibi toplumun ayrılmaz bir parçası olan aile, doğal olarak toplumun sosyal yapısına, değerlerine ve normalarına bağlidır. Bütün bu bilgi, bulgu ve söylemler evlilik ve aile konularına alan uzmanlarının daha fazla ilgi göstermesinin önemine işaret etmektedir. Evliliklerin içeriğini anlamada genel kıstasların yanında, evli kişilerin evlilik olgusuyla ilgili geliştirdikleri öznel düşünceleri de incelemek konunun özel nedenlerini anlamaya yardımcı olacaktır. Çiftlerin evlilikleri ile düşünceleri, zihinlerinde yaptıkları karşılaştırmaların sonucunda vardıkları yargılarla şekillenir. Şöyle ki; çiftlerin, evlilik ilişkisinden elde ettikleri sonuçlar evlilikten beklentilerinin üzerinde olduğunda evlilik olumlu, beklenenin altında olduğunda ise olumsuz olarak algılanmaktadır. Diğer bir deyişle, kişilerin evliliklerine dair algıları, evlilik ilişkilerinden aldıkları ödüller ile ödedikleri bedeller arasındaki farka göre şekillenmektedir. Kişilerin kendi evlilikleri ile ilgili geliştirdikleri bu zihinsel temsiller ise daha sonra evlilik olgusuna dair genellemelerine dönüşür (Hovardaoğlu ve Binici-Azizoğlu, 1996; Sabatelli, 1984). Bireyin herhangi bir konu hakkındaki algısı onun davranışlarına yön verir. Bu algıları tespit etmek ise, bireyin kişisel farkındalığının yanı sıra onun gelecekteki karar ve davranışları ile ilgili ipuçları verebilir. İnsanların herhangi bir konuya, olguya dâir algılarını belirmede farklı yöntemler bulunmaktadır, bu yöntemlerden biri de son yıllarda sosyal bilimlerde sıklıkla kullanılan metafor (eğretileme) analizidir.

Metaforik anlatım (eğretileme) en bilindik anlamıyla, bir olguyu başka bir olguya benzeterek yani başka bir kavramın özelliklerinden hareketle açıklama çabasıdır. Ele alınan kavramı doğrudan anlatmak yerine farklı konulara bağlayarak yani başka tür bir şeye göre açıklamaya çalışmak olarak tanımlanabilir (Collins ve Green, 1990; Johnson ve Malgady, 1979; Krippendroff, 1993). Metaforların soyut konuları bireyin zihinde somutlaştırma ve karmaşık olan konuları basitleştirme gibi işlevleri bulunmaktadır. $\mathrm{Bu}$ kavramlar gelişigüzel olmayıp bireyin gündelik hayatındaki tecrübeleri aracılığ ile zihninde var olan başka kavramlarla asıl kavram arasındaki benzer yönleri harekete geçirerek algılarını ortaya koyduğu bir aktarım biçimidir 
(Lakoff ve Johnson, 2007). Bu araştırmada ele alınan asıl kavram olan evlilik olgusuna dair katılımcı görüşleri de son yıllarda bilimsel çalışmalarda sıklıkla kullanılan metaforlar aracılığıyla incelenmeye çalışılmıştır. Araştırmaya üniversite mezunlarının alınmasının nedeni, daha önce bahsedildiği üzere, boşanma oranları ile eğitim düzeyi arasında bir ilişki olmasındandır. Ayrıca araştırmada, geliştirilen metaforların cinsiyet ve çocuk sâhibi olma değişkenlerine göre incelnmesi de amaç edinilmiştir. Bunun nedeni her iki değişkenin de kişilerin evlilik ile ilgili algılarını etkileyebildiğine dâir öngördür. Çalışmada ortaya konulacak bulguların, rehberlik ve psikolojik danışmanlık ile aile danışmanlığı alanında çalışan uzmanlara farklı bir bakış açıs1 sağlayacağ1 düşünülmektedir. $\mathrm{Bu}$ önemden hareketle araştırmada aşağıdaki sorulara yanıt aranmaya çalışılmıştır:

1. Araştırma kapsamındaki üniversite mezunu evli bireylerin evliliğe ilişkin geliştirdikleri metaforlar nelerdir?

2. Katılımcıların evlilikle ilgili geliştirdikleri metaforlar, benzer özellikleri bağlamında hangi kavramsal kategoriler altında toplanabilir?

3. Araştırma kapsamındaki üniversite mezunu evli bireylerin evliliğe ilişkin geliştirdikleri metaforlar cinsiyetlerine göre nasıldır?

4. Araştırma kapsamındaki üniversite mezunu evli bireylerin evliliğe ilişkin geliştirdikleri metaforlar çocuk sâhibi olup olmamaya göre nasildir?

\section{Yöntem}

\section{Araştırma Modeli}

Araştırma var olan bir durumu var olduğu hâliyle açıklamaya yönelik betimsel bir araştırma olup üniversite mezunu bireylerin evlilik kavramına ilişkin geliştirdikleri metaforları incelemeye yönelik nitel bir araştırmadır. $\mathrm{Bu}$ araştırmada nitel araştırma desenlerinden biri olan "olgubilim” kullanılmıştır. Olgubilim (fenomenoloji) araştırma deseni bildiğimiz ancak ayrıntılı ve derinlemesine bir bilgiye sâhip olmadığımız olgulara odaklanan bir araştırma desenidir. Olgubilim, araştırmacıya tamamen yabancı olmayan, bildiği, ancak tam olarak anlaşılmayan olguları araştırmayı amaçladığı çalışmalar için uygun bir araştırma zemini oluşturur (Yıldırım ve Şimşek, 2008). Metaforlar, bireylerin bir olguya dâir düşüncelerini başka bir mecazla anlatım biçimleridir. Collins ve Green'e (1990) göre metaforlar, özünde bireylerin duygu, anlayış, kavrayış ve düşüncelerinin anlaşılmasında kullanılabilir. 


\section{Örneklem}

Araştırma, araştırmanın amacı çerçevesinde üniversite mezunu ve evli olan 57'si kadın, 43'ü erkek olmak üzere 100 kişi ile yürütülmüştür. Araştırmanın örnekleme yöntemi kartopu örneklemedir. Kartopu örnekleme araştırma konusu ile ilgili bilgisi olan kişilerle çalışmaya başlayıp onların benzer yapılardaki kişilere yönlendirmesi ile gittikçe büyüyen örnekleme yöntemidir (Punch, 2011). Örneklemi oluşturan bireyler 6 farklı yükseköğretim bölümden (psikolojik danışmanlık ve rehberlik, ilahiyat, mühendislik, sosyoloji, hemşirelik ve beden eğitimi) mezundur. Katılımcıların yaşları 24 ile 43 arasında değişmekte olup yaşları ortalaması 29'dur.

\section{Veri Toplama Araçları}

Araştırmanın verileri iki bölümden oluşan anket formu ile toplanmıştır. Anket formunun ilk bölümünde katılımcıların demografik bilgilerine (cinsiyet, yaş, mezun olunan bölüm ve çocuk sâhibi olup olmama) dair sorular bulunmaktadır. İkinci bölümde ise katılımcıların evlilik olgusuna dâir geliştirdikleri metaforları belirlemek amacıyla formun başında metaforun kısa bir tanımı verilmiştir. Alt kısmına ise "Evlilik ............. gibidir, çünkü .." cümlesi konularak katılımcılardan bu cümleyi tamamlamaları istenmiştir. Yıldırım ve Şimşek'e (2008) göre, metaforlar tek başlarına betimsel veya görsel gücünü yeteri kadar ortaya çıkartmayacaktır. Metaforun alınmasının ardından mutlaka "neden" veya "niçin" sorusu da yöneltilmelidir. Mecazların asıl gücü, bu sıfatlarla ilgili sorudadır. Çünkü her birey, aynı metafora farklı anlamlar yükleyebilir. Yüklenen bu farklı anlamları veya bir metaforu kullanırken hangi amaçla kullanıldığı ancak "niçin" sorusuna verilen yanıtlarla görülebilir. Katılımcılara bu noktada araştırmacı tarafindan başka bir kavrama dâir metafor örneği verilerek cümleyi nasıl dolduracaklarına dâir bir açıklama yapılmıştır.

\section{Verilerin Analizi ve Çözümlenmesi}

Veri toplama aracı gönüllülük esasına göre uygulanmıştır. Belirtilmiş kartopu örnekleme yönteminin doğası gereği ulaşılabilen üniversite mezunu evli bireylere ilgili form verilmiş ve doldurmaları istenmiştir. Verdikleri bilgilerin gizliliği konusu özellikle vurgulanmıştır. Daha sonra bu katılımcılardan etraflarındaki evli ve üniversite mezunları olup olmadığ sorulmuş ve yaptıkları yönledirmelerle sonraki katılımcılara ulaşılmıştır. 
Bütün uygulamalar bittikten sonra araştırma dâhilindeki bireylerin evlilik olgusuna dâir geliştirdikleri metaforlar üç aşamada analiz edilmiştir:

1. Aşama: Kodlama ve ayıklama: İlk aşamada öncelikle katılımcıların ürettikleri metaforları açık ve anlaşılır bir şekilde üretip üretmediklerine bakılmıştır. Daha sonra katılımcıların geliştirdikleri metaforların kodlanmasına geçilmiştir. Ancak bazı katılımcıların geliştirdikleri metaforların yeterince açık olmadığı veya geliştirilen metaforun "neden" ve "niçin"leri net olarak ifade edilmediği görülerek toplam 25 katılımcının formu iptal edilmiştir. Sonuçta toplam 47 adet farklı geçerli metafora ulaşılmıştır. Ulaşılan bu metaforlar yeniden alfabetik siraya göre dizilerek ham veriler ikinci kez gözden geçirilmiş ve her metaforu açıklayan katılımcı ifadeleri gözden geçirilmiştir. Metaforların birbirleri ile ilişkileri görülmeye çalışılmış, benzer düşüncelerle yazılmış olanlar gruplandırılmış ve böylece metaforların kategorileştirilmesi ve veri analizi süreci geçerli kılınmaya çalışılmıştır.

2. Aşama: Kategori geliştirme: $\mathrm{Bu}$ aşamada, geliştirilen metaforlar ve her bir metaforlara getirilen açıklamalara dair incelemelere göre ortak yönler bir araya getirilerek toplam 6 ayrı kategori elde edilmiştir. Ayrıca her metafor yüklenen anlamın olumlu mu olumsuz mu oluşuna göre değerlendirilmiştir. Bu kategoriler aşağıdaki tabloda verilmiştir:

Tablo 1. Evliliğe İlişkin Altı Kavramsal Kategori

\begin{tabular}{lll}
\hline Kategori & Metaforlar & Ortak Tema \\
\hline $\begin{array}{l}\text { 1. Yiyecek-içecek gibi } \\
\text { tat veren bir olgu olarak } \\
\text { evlilik }\end{array}$ & $\begin{array}{l}\text { Elma, salata, çikolata, tuz, şarap, } \\
\text { ceviz, tatlı, su, ekmek, tost, sakız, } \\
\text { biber, kış armudu, nar, makarna, } \\
\text { baklava }\end{array}$ & $\begin{array}{l}\text { Evliliğin olumlu veya } \\
\text { olumsuz bir tat bırakması }\end{array}$ \\
\hline $\begin{array}{l}\text { 2. Hayatı zorlayıcı bir } \\
\text { olgu olarak evlilik }\end{array}$ & $\begin{array}{l}\text { Savaş, bakıcılık, integral, ruhsuz- } \\
\text { luk }\end{array}$ & $\begin{array}{l}\text { Evliliğin hayatı keyifsiz } \\
\text { bir hale getirmesi }\end{array}$ \\
\hline $\begin{array}{l}\text { 3. Hayatı kolaylaştırıcı } \\
\text { bir olgu olarak evlilik }\end{array}$ & $\begin{array}{l}\text { Tek vücut, dans, cennet, sultanlık, } \\
\text { rüya }\end{array}$ & $\begin{array}{l}\text { Evliliğin hayatı daha ke- } \\
\text { yifli bir hale getirmesi }\end{array}$ \\
\hline $\begin{array}{l}\text { 4. Aydınlatıcı bir olgu } \\
\text { olarak evlilik }\end{array}$ & Işı, ayna, güneş, okul & $\begin{array}{l}\text { Evliliğin öğreticiliği, kişi- } \\
\text { nin kendini tanımasına }\end{array}$ \\
\hline $\begin{array}{l}\text { 5. Üretkenlik sağlayan } \\
\text { bir olgu olarak evlilik }\end{array}$ & $\begin{array}{l}\text { Ağaç, tarla, çiçek, toprak, bahçe, } \\
\text { yağmur }\end{array}$ & $\begin{array}{l}\text { Evliliğin çoğalma ve kişiyi } \\
\text { daha üretici bir hâle ge- } \\
\text { tirmesi }\end{array}$ \\
\hline $\begin{array}{l}\text { 6. Değişken bir olgu } \\
\text { olarak evlilik }\end{array}$ & $\begin{array}{l}\text { Yol, gemi, deniz, film, mevsimler, } \\
\text { saat, seyahat, gökkuşağ1, yeni } \\
\text { sayfa, dönme dolap, kutu, resim }\end{array}$ & $\begin{array}{l}\text { bazen olumsun bazen olumlu yönlerinin } \\
\text { olması }\end{array}$ \\
\hline
\end{tabular}


3. Aşama: Geçerlik ve güvenirliği sağlama: Nitel araştırmalarda geçerlik ve güvenirliği sağlamanın en önemli ölçütlerinden biri, verilerin ve toplanma süreçlerinin mümkün olduğunca ayrıntılı olarak rapor edilmesi ve araştırmacının elde ettiği sonuçlara nasıl ulaştığını net bir biçimde ifade etmesidir (Kumar, 2011; Merriam, 2015; Yıldırım ve Şimşek, 2008). Bu çalışmada da analizlerin geçerliğini sağlamak için metaforların hangi kategorilere niçin girdiği açıkça ifade edilmeye çalışılmıştır. Ayrıca bulgular kısmında her kategoriye giren metaforlara âit katılımcı açılamalarına dâir örnekler, kat1lımcıların kimlik bilgileri saklı tutularak forma yazıldığı hâliyle doğrudan verilmiştir.

Araştırmanın güvenirliğini sağlamak için geliştirilen metaforların kategorileri temsil edip etmediğini netleştirmek için etmek için iki alan uzmanının görüşüne başvurulmuştur. Bu iki uzmana, 6 kavramsal kategorinin isimleri, hangi metaforların bu kavramsal kategoride yer aldığını ve her kategorideki metaforlarla ilgili ortak noktaları içeren bir liste verilerek incelemeleri istenmiştir. Uzman değerlendirmelerinin ardından görüş birliği ve görüş ayrılığ değerleri belirlenmiştir. Araştırmanın güvenilirlik hesaplaması için Miles ve Huberman'ın (1994) önerdiği aşağıdaki uyuşum formülü kullanılmıştır. Bu noktada 4 metafor ve yüklenen anlam arasında (kutu, resim, tek vücut, ayna) net bağlantılar kurulamamış ve uzmanlarla görüş ayrılığına düşülmüştür. $\mathrm{Bu}$ durum neticesinde, aşağıdaki formüle göre hesaplanan güvenirlik katsayısı 0.91 olarak hesaplanmıştır.

\section{Güvenirlik=Görüş birliği/(Görüş birliği+Görüş̧ ayrılı̆̆g)}

Güvenirlik=43/(43+4)=0.91

Elde edilen bu değer, yapılan kategorileştirme çalışması analizlerinin güvenilir olduğunu göstermektedir.

\section{Bulgular}

Araştırma kapsamındaki bireylerin ürettikleri metaforlara ilişkin bulgular öncelikle genel olarak ele alınmış, daha sonra bu metaforlar cinsiyet ve çocuk sâhibi olup olmama değişkenlerine göre kategorileştirilerek verilmiştir.

Tablo 2'de görüleceği gibi, araştırma kapsamındaki evli bireyler evlilikle ilgili toplam 100 adet ve 47 farklı metafor üretmişlerdir. Üretilen 
metaforların ortak özelliklerinden hareketle oluşturulan temalarının frekanslarına göre dağılımı şu şekilde olmuştur: Yiyecek-içecek gibi tat veren bir olgu olarak evlilik 29 (\%29), hayatı zorlayıcı bir olgu olarak evlilik 9 (\%9), hayatı kolaylaştırıcı bir olgu olarak evlilik 15 (\%15), aydınlatıcı bir olgu olarak evlilik 9 (\%9), üretkenlik sağlayan bir olgu olarak evlilik 11 (\%11) ve değişken bir olgu olarak evlilik 27 (\%27)'dir. Katılımcıların oluşturdukları toplam 100 metaforun 76'sına (\%76) olumlu anlamlar yüklenmiş, 24'üne ise (\%24) olumsuz anlamlar yüklenmiştir.

Oluşturulan temalar bağlamında, katılımcılar tarafindan oluşturulan metaforlar ve yüklenen anlamlara dâir orijinal örnekler aşağıda verilmiştir. Her metaforun önüne olumlu anlam yüklenenler için artı (+), olumsuz anlam yüklenenler için ise eksi (-) işareti konulmuştur.

Tablo 2. Katılımcıların Ürettikleri Metaforların Genel Dağılımı

\begin{tabular}{|c|c|c|c|c|c|c|}
\hline TEMA & $\begin{array}{l}\text { OLUMLU } \\
\text { METAFORLAR }\end{array}$ & $\begin{array}{c}\sum \mathbf{f} / \% \\
(+)\end{array}$ & $\begin{array}{l}\text { OLUMSUZ } \\
\text { METAFORLAR }\end{array}$ & $\begin{array}{c}\sum \mathbf{f} / \% \\
(-)\end{array}$ & $\sum \mathbf{f}$ & $\sum \%$ \\
\hline 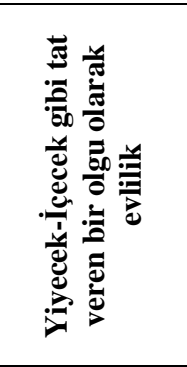 & $\begin{array}{l}\text { Elma (4), } \\
\text { Salata (3) } \\
\text { Çikolata (3) } \\
\text { Tuz (3) } \\
\text { Şarap (2) } \\
\text { Ceviz (1) } \\
\text { Tatlı (1) } \\
\text { Su (1) } \\
\text { Ekmek (1) } \\
\text { Tost (1) }\end{array}$ & $f=20$ & $\begin{array}{l}\text { Sakız (3) } \\
\text { Biber (2) } \\
\text { Kış armudu (1) } \\
\text { Nar (1) } \\
\text { Makarna (1) } \\
\text { Baklava (1) }\end{array}$ & 9 & 29 & $\% 29$ \\
\hline 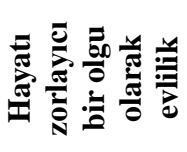 & - & - & $\begin{array}{l}\text { Savaş (5) } \\
\text { Bakıcılık (2) } \\
\text { İtegral (1) } \\
\text { Ruhsuzluk (1) }\end{array}$ & 9 & 9 & $\% 9$ \\
\hline 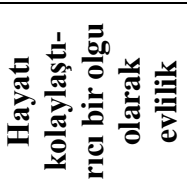 & $\begin{array}{l}\text { Tek vücut (7) } \\
\text { Dans (3) } \\
\text { Cennet (2) } \\
\text { Sultanlık (2) } \\
\text { Rüya (1) }\end{array}$ & 15 & - & - & 15 & $\% 15$ \\
\hline 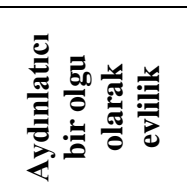 & $\begin{array}{l}\text { Işık (4) } \\
\text { Ayna (3) } \\
\text { Güneş (1) } \\
\text { Okul (1) }\end{array}$ & 9 & - & - & 9 & $\% 9$ \\
\hline
\end{tabular}




\begin{tabular}{|c|c|c|c|c|c|c|}
\hline 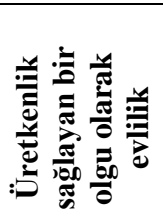 & $\begin{array}{l}\text { Ağaç (3) } \\
\text { Tarla (3) } \\
\text { Çiçek (2) } \\
\text { Toprak (1) } \\
\text { Bahçe (1) } \\
\text { Yağmur (1) }\end{array}$ & 11 & - & - & 11 & $\% 11$ \\
\hline 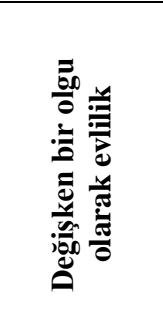 & $\begin{array}{l}\text { Yol (6) } \\
\text { Gemi (5) } \\
\text { Deniz (3) } \\
\text { Film (2) } \\
\text { Mevsimler (1) } \\
\text { Saat (1) } \\
\text { Seyahat (1) } \\
\text { Gökkuşağı (1) } \\
\text { Yeni Sayfa (1) }\end{array}$ & 21 & $\begin{array}{l}\text { Dönme dolap (4) } \\
\text { Kutu (1) } \\
\text { Resim (1) }\end{array}$ & 6 & 27 & $\% 27$ \\
\hline Toplam & $f=76 ; \% 76$ & & $f=24 ; \% 24$ & & 100 & 100 \\
\hline
\end{tabular}

\section{TEMA: Yiyecek-İçecek Gibi Tat Veren Bir Olgu Olarak Evlilik}

+Elma: Eşler birbirini tamamlamak suretiyle bir bütünlük yaratır.

+Çikolata: Çok severek, arzu ederek yaşamaya (yemeye) devam edersin. Ağızda sürekli olarak harika bir tat bırakır.

-Baklava: Başlangıçta tatlı ve lezzetli gibi görünse de aslında oldukça zararlıdır.

-Nar: Asla dışından anlaşılmaz. Ne zamanki içine girersin o zaman ekşi bir tadı olduğunu ve çok sert çekirdekleri olduğunu anlarsın.

\section{TEMA: Hayatı Zorlayıcı Bir Olgu Olarak Evlilik}

-Savaş: Bir kargaşa, bir gürültü, birbirine söz geçirme sanatı gibi geliyor bana. Kim sözünü daha fazla geçiriyorsa o savaşı kazanmıştır. -Bakıcılık: Emek verir, şefkat verir özenirsin. Yani sürekli fedakarlık edersin ama sana dönüşü olumsuz olur. En ufak eksikliğin yüzüne vurulur ve yalniz kalırsin.

\section{TEMA: Hayatı Kolaylaştırıcı Bir Olgu Olarak Evlilik}

+Tek Vücut: Bir kişi olmaktır.

+Sultanlık: Bekârlık sultanlıktır diyenlere verdiğim cevaptır. Insan sorumluluk altına girer ve bir evi yönetmeye başlar. Yönetebildiğini, kimseye muhtaç olmadığını gördükçe de kendini sultan gibi hissetmeye başlar. 


\section{TEMA: Aydınlatıcı Bir Olgu Olarak Evlilik}

+Işık: Etrafa sevgi ve saygı olarak ışık huzmeleri yaydıkça ve paylaşılınca mutluluğun artmasına vesile olur.

+Ayna: Bakmasını bilirsen kendini görürsün.

\section{TEMA: Üretkenlik Sağlayan Bir Olgu Olarak Evlilik}

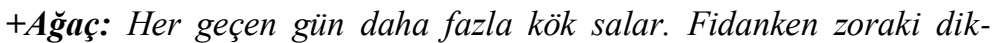
ilmemişse ve iklimine uygun doğru zamanda dikimi yapılmışsa yıllarca orada kök salar, gittikçe büyür ve ihtişam kazanır ve herkes güzelliğine hayran kalır.

+Tarla: Insanın hem hayatı bereketlenir hem de çoğalmasını să̆lar.

\section{TEMA: Değişken Bir Olgu Olarak Evlilik}

+Gemi: İçinde harika maviliklerde yol alırsın ama zaman zaman bu mavilik sıkıcı gelir.

+Film: Kendin yazar kendin oynarsin ve asla bitmesini istemezsin. Ama içinde elbette bazen kahkaha bazen de gözyaşı vardır.

-Dönme Dolap: Yıllar geçtikçe farklı yönleri görmene rağmen sürekli aynı noktaya döndüğünü anlarsın. Başta eğlenirsin, keyif alırsın ama bir süre sonra miden bulanır. Hiç ĕglenceli değildir.

Tablo 3. Katılımcıların Ürettikleri Metaforların Cinsiyetlerine Göre Dağılımı

\begin{tabular}{|c|c|c|c|c|c|c|}
\hline TEMA & $\begin{array}{l}\text { METAFORLAR } \\
\text { (Kadın) }\end{array}$ & $\underset{(+)}{\sum \mathbf{f} / \%}$ & $\begin{array}{c}\sum \mathbf{f} / \% \\
(-)\end{array}$ & $\begin{array}{l}\text { METAFORLAR } \\
\text { (Erkek) }\end{array}$ & $\begin{array}{c}\sum \mathbf{f} / \% \\
(+)\end{array}$ & $\begin{array}{c}\sum \mathbf{f} / \% \\
(-)\end{array}$ \\
\hline 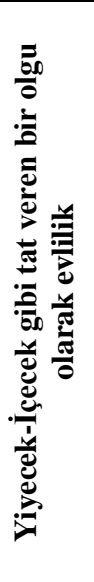 & 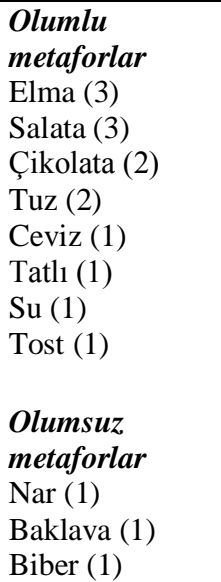 & $\% 82.35$ & $\begin{array}{c}\mathrm{f}=3 \\
\% 17.65\end{array}$ & 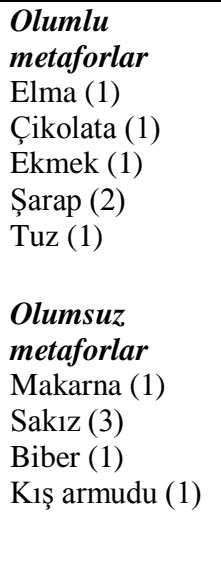 & $\% 50$ & $f=6$ \\
\hline
\end{tabular}




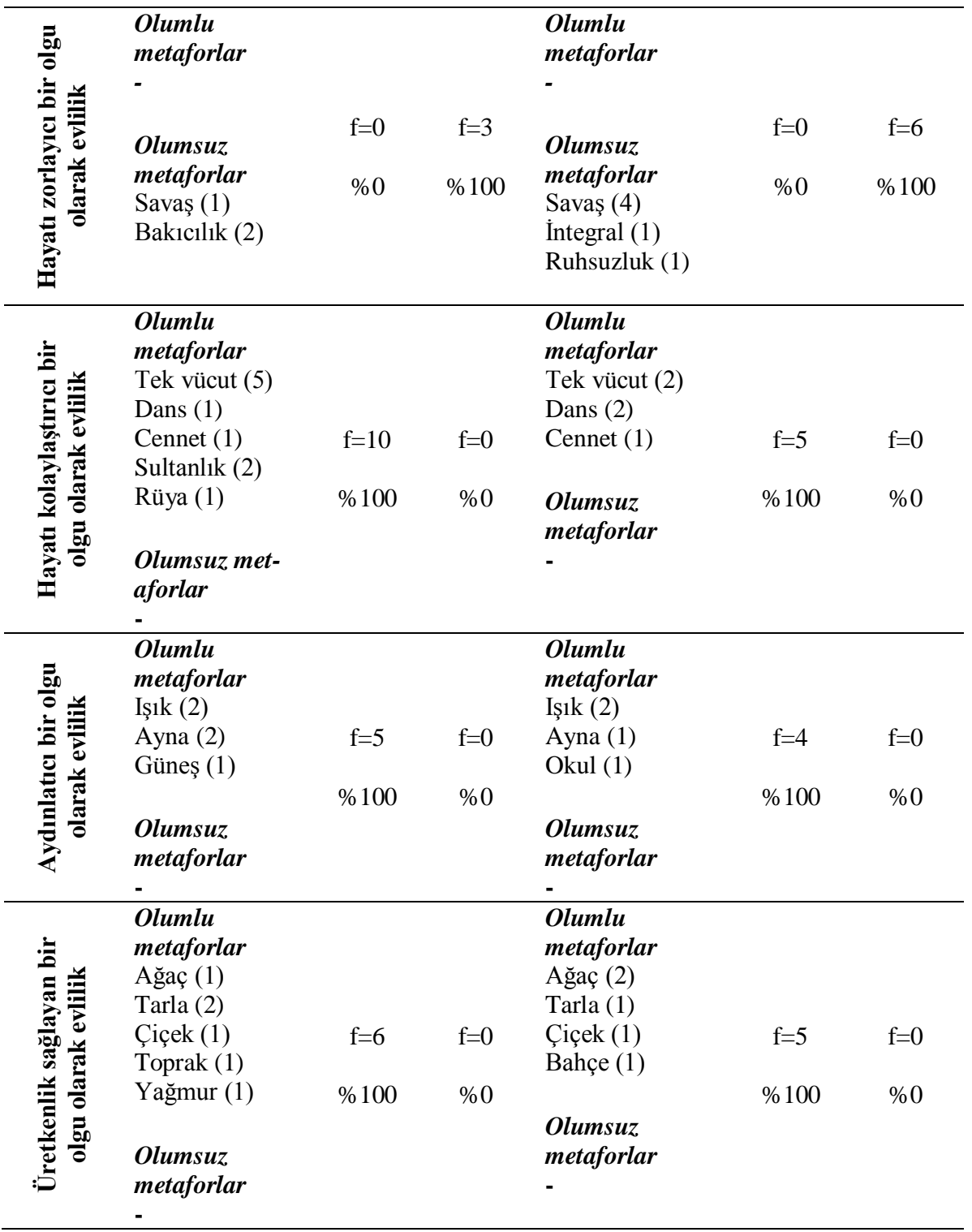




\begin{tabular}{|c|c|c|c|c|c|c|}
\hline 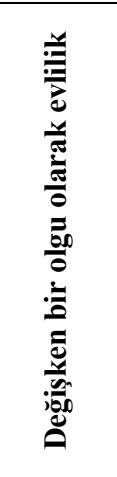 & $\begin{array}{l}\text { Olumlu } \\
\text { metaforlar } \\
\text { Yol (4) } \\
\text { Gemi (4) } \\
\text { Deniz (3) } \\
\text { Mevsimler (1) } \\
\text { Saat (1) } \\
\text { Yeni Sayfa (1) } \\
\\
\text { Olumsuz } \\
\text { metaforlar } \\
\text { Dönme dolap (1) } \\
\text { Kutu (1) }\end{array}$ & $\begin{array}{c}\mathrm{f}=14 \\
\% 87.50\end{array}$ & $\begin{array}{c}\mathrm{f}=2 \\
\% 12.5\end{array}$ & 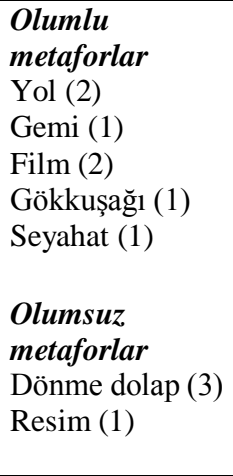 & $\begin{array}{c}f=7 \\
\% 63.65\end{array}$ & $\begin{array}{c}\mathrm{f}=4 \\
\% 36.35\end{array}$ \\
\hline Toplam & 57 & $\begin{array}{c}\mathrm{f}=49 \\
\% 85.96\end{array}$ & $\begin{array}{c}\mathrm{f}=8 \\
\% 14.04\end{array}$ & 43 & $\begin{array}{c}\mathrm{f}=27 \\
\% 62.79\end{array}$ & $\begin{array}{c}\mathrm{f}=16 \\
\% 37.21\end{array}$ \\
\hline
\end{tabular}

Tablo 3 incelendiğinde; katılımcıların ürettikleri metaforların ve bu metaforlara yükledikleri anlamların cinsiyetlerine göre, ne yönde değişim gösterdiğini belirlemek için yapılan kategorileştirme sonucunda her bir temanın cinsiyete göre dağılımının şu şekilde gerçekleştiği görülmüştür: "Yiyecek-içecek gibi tat veren bir olgu olarak evlilik" temasında kadınların ürettikleri toplam 17 metaforun 14'ünün (\%82.35) olumlu, 3'ünün (\%17.65) ise olumsuz, erkeklerin ürettikleri toplam 12 metaforun 6'sının (\%50) olumlu, yine 6'sının (\%50) olumsuz olduğu görülmüştür. İçeriği olumsuz kavramlarla şekillenen, "Hayatı zorlayıcı bir olgu olarak evlilik" temasında kadınların ürettiği 3, erkeklerin oluşturduğu toplam 6 olumsuz metaforun olduğu belirlenmiştir. İçeriği olumlu kavramlarla oluşan, "Hayatı kolaylaştırıcı bir olgu olarak evlilik" temasında ise kadınların geliştirdiği 10, erkeklerin geliştirdiği toplam 5 olumlu metafor olduğu göze çarpmıştır. Yine içeriği tamamen olumlu yüklemelerle oluşmuş olan, "aydınlatıcı bir olgu olarak evlilik" temasında kadınların ürettiği toplam 5, erkeklerin ürettikleri toplam 4 olumlu metafor olduğu görülmüştür. Yüklenen anlamların tamamının olumlu olduğu bir diğer tema olan "üretkenlik sağlayan bir olgu olarak evlilik" temasında ise kadınların oluşturduğu toplam 6 , erkeklerin ürettiği toplam 5 olumlu metafor saptanmışır. Son olarak "değişken bir olgu olarak evlilik" temasında kadınların ürettikleri toplam 16 metaforun 14'ünün (\%87.50) olumlu, sadece 2'sinin (\%12.50) ise olumsuz, erkeklerin ürettikleri toplam 11 metaforun 7'sinin (63.65) olumlu, 4'ünün ise (\%36.35) olumsuz olduğu görülmüştür. Genel olarak bakıldığında; kadınların oluşturdukları toplam 57 metaforun 49'una (\%85.96) olumlu, sadece 8'ine (\%14.04) olumsuz anlamlar yüklenmiş olduğu görülmüştür. Erkek katılımcıların geliştirdikleri toplam 43 metaforun 
27'sine (\%62.79) olumlu, 16'sına ise (\%37.21) olumsuz anlamlar yüklendiği belirlenmiştir.

Katılımcıların oluşturduğu temalar çerçevesinde, katılımcıların oluşturduğu metaforlara ve yüklenen anlamlara dâir orijinal örnekler her iki cinsiyet için aşağıda verilmiştir. Yine her metaforun önüne olumlu anlam yüklenenler için artı (+), olumsuz anlam yüklenenler için ise eksi (-) işareti konulmuş ve hangi cinsiyet tarafindan üretildiği $(\mathrm{K})$ ve $(\mathrm{E})$ harfleri ile gösterilmiştir.

\section{TEMA: Yiyecek-İçecek Gibi Tat Veren Bir Olgu Olarak Evlilik}

(E)+Ceviz: Dışardan sert görünür; ancak o kötü görüntünün içinde bir lezzet gizlidir.

(K)+Çikolata: Çok sevdiğin şeyleri paylaşmak zordur. Ancak çok sevdiğin kişilerle paylaşmak istersin ve o zaman daha lezzetli olur.

(E)-Sakız: Başta güzel bir tadı vardır; ama çiğnedikçe yani zamanla tadı kaçar, bozulur, çenen yorulur.

(K)-Biber: Belki önce lezzetli gelebilir; ama kesinlikle canınız yanar. Üstelik vazgeçtiğiniz anda acısı geçmez yakmaya uzun süre devam eder.

\section{TEMA: Hayatı Zorlayıcı Bir Olgu Olarak Evlilik}

(E)-Integral: Çözmeye çalıştıkça zorlaşır, zorlaştıkça beynin yanar; ama çözmesi çok zordur her halükarda.

(K)-Bakıcılık: Senden çocuk bakman, yemek yapman, evi temizlemen, ütü yapman vb. bir sürü şey beklenir. Karşılığında ise teşekkürü bile zor bulursun.

\section{TEMA: Hayatı Kolaylaştırıcı Bir Olgu Olarak Evlilik}

(K)+Rüya: Her sabah yanınızda birinin uyuyor olduğunu görmek gerçek üstü bir şey. Kötü bir anda onun yanınızda uyuyor olması durumu düzeltir size güven verir.

(E)+Cennet: Evlilik huzur verir. Sevdiğin insanın her zaman her istediğinde yanında olması dünyada yaşayabileceğin en güzel duygudur. Özellikle bu helâl daire içinde olduğu için.

\section{TEMA: Aydınlatıcı Bir Olgu Olarak Evlilik}

(K)+Ayna: Kendi ruhunu aynada görmek gibidir. Güzel bir yemek yaparsın, eşin "eline sağllk" der ve mutlu olursun. Karşılıklı ruhun 
birbirinde görmesidir işte bu.

(E)+ Okul: Tanıdıkça öğrenirsiniz, seversiniz, âşık olursunuz. Bazen bitsin tatil olsun istersiniz; ama içinde ögrendiklerinizi anımsar ve özlersiniz.

\section{TEMA: Üretkenlik Sağlayan Bir Olgu Olarak Evlilik}

(E)+A $\breve{g}$ aç: Önce sen bir tek iken, bir tek çekirdek iken evlilik akdiyle o çekirdeğin büyüyüp yeşermesi meyveleriyle de çocukların olması güzel bir şeydir.

(K) +Toprak: Sarar, sarmalar güven verir ve çoğalmayı să̆lar.

\section{TEMA: Değişken Bir Olgu Olarak Evlilik}

(K)+Gemi: Ister firtınall, ister dingin olsun deniz birlikte gögüs gerip yeni umutlara birlikte yelken açarsinız.

(E)+Seyahat: Gidilecek onca yol, görülecek bir sürü yer ancak bu yolla olur.

(K)-Kutu: Içinde ne olduğunu bilemezsin, bazen çok hoşuna giden şeyler çıkar bazen ise hiç sevmeyeceğin şeylerle karşılaşırsın.

(E)-Dönme Dolap: Döner dolaşır aynı noktaya gelirsin. Ancak bu o kadar çabuk olur ki yılların nasıl geçtiğini anlamazsın. Eğlenceli olduğunu sanarak binip korkunuzdan feyz alırsınız.

Tablo 4. Katılımcıların Ürettikleri Metaforların Çocuk Sahibi Olma Değişkenine Göre Dağılımı

\begin{tabular}{|c|c|c|c|c|c|c|}
\hline TEMA & $\begin{array}{c}\text { METAFORLAR } \\
\text { (Çocuk Var) }\end{array}$ & $\begin{array}{c}\sum \mathbf{f} / \% \\
(+)\end{array}$ & $\begin{array}{c}\sum \mathbf{f} / \% \\
(-)\end{array}$ & $\begin{array}{c}\text { METAFORLAR } \\
\text { (Çocuk Yok) }\end{array}$ & $\begin{array}{c}\sum \mathbf{f} / \% \\
(+)\end{array}$ & $\begin{array}{c}\sum \mathbf{f} / \% \\
(-)\end{array}$ \\
\hline 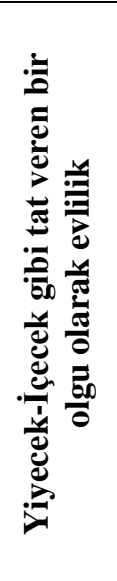 & 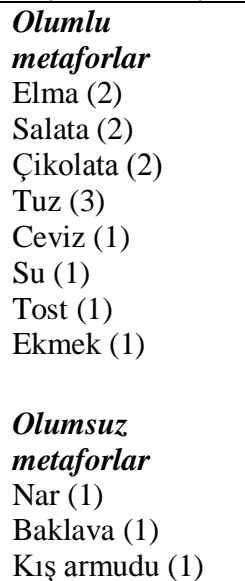 & $\begin{array}{c}f=13 \\
\% 81.25\end{array}$ & $\begin{array}{c}f=3 \\
\% 18.75\end{array}$ & $\begin{array}{l}\text { Olumlu } \\
\text { metaforlar } \\
\text { Elma (2) } \\
\text { Çikolata (1) } \\
\text { Şarap (2) } \\
\text { Tatli (1) } \\
\text { Salata (1) } \\
\text { Olumsuz } \\
\text { metaforlar } \\
\text { Makarna (1) } \\
\text { Sak1z (3) } \\
\text { Biber (2) }\end{array}$ & $\begin{array}{c}\mathrm{f}=7 \\
\% 53.85\end{array}$ & $\begin{array}{c}f=6 \\
\% 46.15\end{array}$ \\
\hline
\end{tabular}




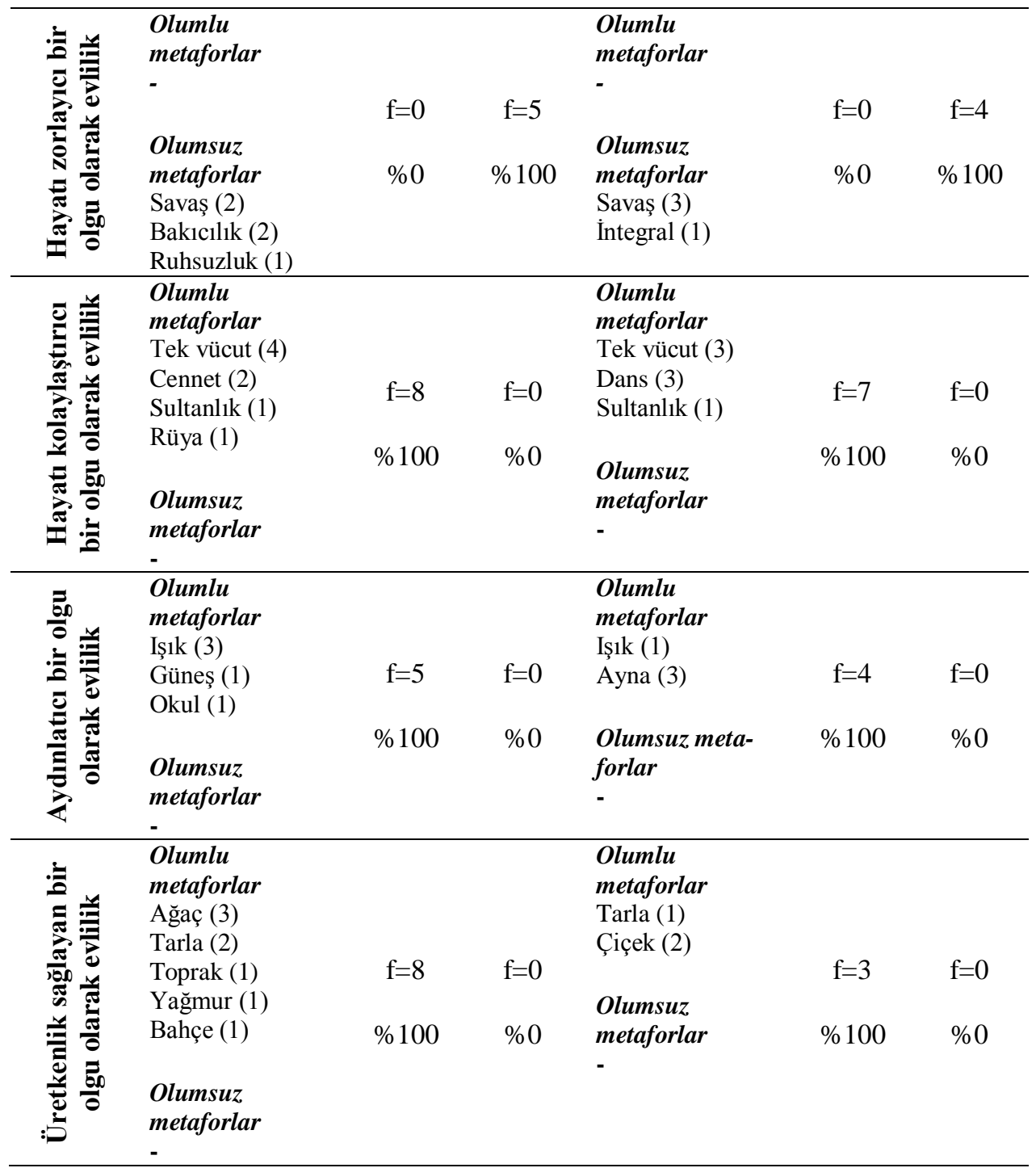




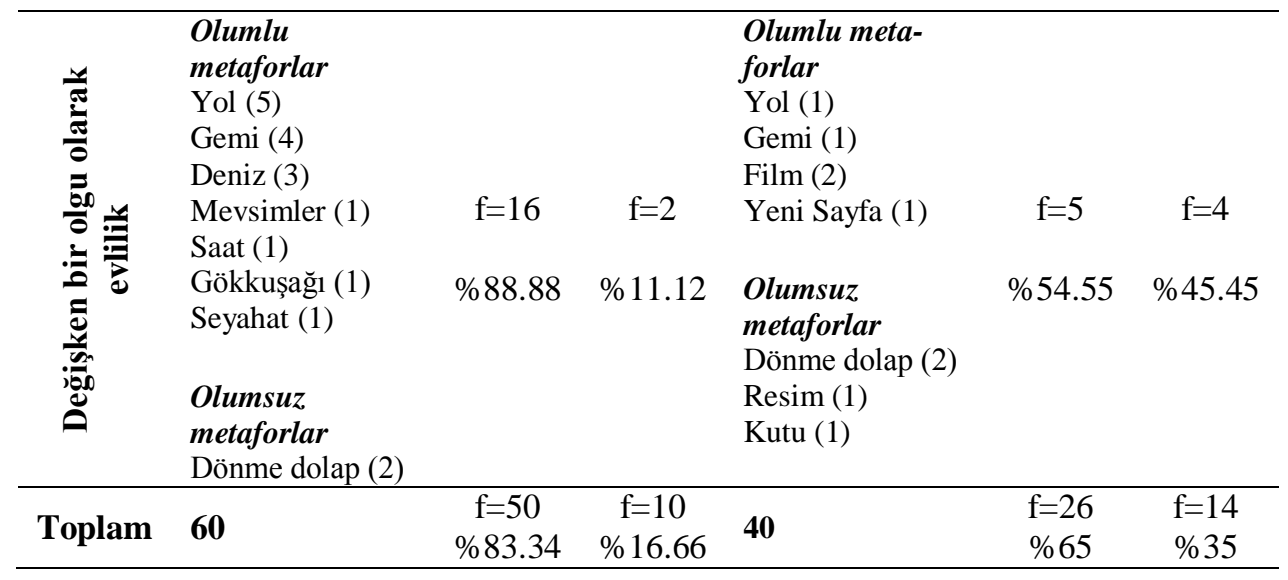

Tablo 4 ele alındığında; katılımcıların geliştirdikleri metaforların ve bu metaforlara yükledikleri anlamların çocuk sâhibi olup olmamalarına göre ne yönde farklılaştığını görmek için yapılan kategorileştirme çalışması sonucunda: "Yiyecek-içecek gibi tat veren bir olgu olarak evlilik" temasında çocuk sâhibi olanların ürettikleri toplam 16 metaforun 13'ünün (\%81.25) olumlu, 3'ünün (\%18.75) ise olumsuz, çocuğu olmayanların ürettiği toplam 13 metaforun 7'sinin (\%53.85) olumlu, 6'sinın (\%47.15) olumsuz olduğu belirlenmiştir. "Hayatı zorlayıcı bir olgu olarak evlilik" temasında çocuğu olanların ürettiği toplam 5 , çocuğu olamayanların ise oluşturduğu toplam 4 olumsuz metaforun olduğu saptanmıştır. "Hayatı kolaylaştırıcı bir olgu olarak evlilik" temasında ise çocuk sâhibi olanların geliştirdiği toplam 8, çocuk sahibi olmayanların ise geliştirdiği toplam 7 olumlu metafor olduğu belirlenmiştir. "Aydınlatıcı bir olgu olarak evlilik" temasında çocuğu olanların ürettiği toplam 5, çocuğu olmayanların ürettiği toplam 4 olumlu metafor olduğu göze çarpmıştır. "Üretkenlik sağlayan bir olgu olarak evlilik" temasında ise çocuğu olanların oluşturduğu toplam 8 , çocuk sahibi olamayanların ürettiği toplam 3 olumlu metafor belirlenmiştir. Son olarak ise, "değişken bir olgu olarak evlilik" temasında çocuğu olanların ürettikleri toplam 18 metaforun 16'sinin (\%88.88) olumlu, sadece 2'sinin (\%11.12) ise olumsuz, çocuk sahibi olmayanların ürettikleri toplam 9 metaforun 5 'inin (54.55) olumlu, 4'ünün ise (\%45.45) olumsuz olduğu görülmüştür. Genel olarak bakıldığında; çocuğu olan katılımcıların oluşturdukları toplam 60 metaforun 50'sine (\%83.34) olumlu, yalnızca 10'una (\%16.66) olumsuz anlamlar yüklenmiştir. Çocuk sâhibi olmayan katılımcıların geliştirdikleri toplam 40 metaforun 26'sina (\%65) olumlu, 14'üne ise (\%35) olumsuz an- 
lamlar yüklenmiş olduğu görülmüşstür.

Katılımcıların geliştirdikleri metaforlara ve yüklenen anlamlara dâir orijinal örnekler hem çocuk sâhibi olan hem de çocuk sâhibi olmayanlar için aşağıda sunulmuştur. Her metaforun önüne çocuğu olanlar (ÇV), çocuğu olmayanlar ise (ÇY) sembolleri ile gösterilmiştir.

\section{TEMA: Yiyecek-İçecek Gibi Tat Veren Bir Olgu Olarak Evlilik}

(ÇV)+Salata: İçinde aradı̆̆ın her şeyi bulabilirsin. Farklı tatlar bir araya gelerek lezzetli bir harman oluşturur ve üstelik sağllklıdır.

(ÇY)+Tatlı: A ğzında hoş bir tat bırakur. Yedikçe yemek istersin.

(ÇV)-Kış Armudu: Uzaktan güzel görünür ama yiyince insanın boğazına takilır.

(ÇY)-Makarna: Bekârken sevdiğin evlenince arttk basit gelen makarna yemeği gibi, bekarken evliliği güzel sanarsin ama evlenince öyle olmadığını görürsün.

\section{TEMA: Hayatı Zorlayıcı Bir Olgu Olarak Evlilik}

(ÇV)-Ruhsuzluk: Enerjinizi yitir, sıradanlaşırsınız. (ÇY)-Savaş: Egolar karşı karşıya gelir ve sürekli biri diğerini yenmeye çalışır. Kafanda sürekli karşı tarafi yenmenin yolları vardır.

\section{TEMA: Hayatı Kolaylaştırıcı Bir Olgu Olarak Evlilik}

(ÇV)+Cennet: Bu dünyanin güzelliklerini ancak evlenince yaşarsiniz. Hayırlı bir eş, sağllklı evlatlar cennet değildir de nedir?

(ÇY)+Dans: Adlmları birbirine göre atmak, partnerlerin birbirlerine uyum sağlamasıdır. Tek başına yapmaya kalktı̆̆ında eksik kalırsin; ancak birlikte yapıldı̆ğnda daha kolay hale gelir.

\section{TEMA: Aydınlatıcı Bir Olgu Olarak Evlilik}

(ÇV)+Güneş: İ̧̧ini ıstıtr, karanlık yönlerini aydınlatır, kendini keşfettirir.

(ÇY)+Ayna: İnsanın karşısındakine bakarken kendini görüp içini dökmesi, bütün bunlarl yaparken kendini tanımast, hayattan zevk almasidir. 


\section{TEMA: Üretkenlik Sağlayan Bir Olgu Olarak Evlilik}

(ÇV)+Bahçe: İ̧̧inde birçok güzelliği aynı anda barındırır. Her köşesi ayrı güzeldir, ayr huzur verir.

(ÇY)+Çiçek: Çiçek gibi hayata güzellik katar. İlgi, bakım, sevgi ister. İstediği bakımı verdikçe sizi mutlu etmeye devam eder.

\section{TEMA: Değișken Bir Olgu Olarak Evlilik}

(ÇV)+Gökkuşağı: Bütün renkleri içerir. Bu renklerden bazılarını seversin bazllarin sevmezsin.

(ÇY)+Yeni Sayfa: Hayata bembeyaz bir sayfa açarsın. Üstelik istediğin her şeyi bu yeni açtı̆ın temiz sayfaya yazabilirsin.

(ÇV)-Dönme Dolap: Mide bulandirtr. Bir iyi bir kötü. Binmeye gerek yok.

(ÇY)-Resim: Kimisi beğenir, kimisi beğenmez.

\section{Tartışma ve Sonuç}

$\mathrm{Bu}$ araştırmanın temel amacı, üniversite mezunu evli bireylerin evlilik ile ilgili algılarını onların ürettikleri metaforların analizi yoluyla ele almaktır. $\mathrm{Bu}$ ana amaç çerçevesinde öncelikle katılımcıların ürettikleri metaforların ve bu metaforların benzer özelliklerinden hareketle oluşturulabilecek kavramsal kategorilerin neler olabileceğine yönelik bir inceleme yapılmıştır. Elde edilen sonuçlara göre; araştırma kapsamındaki evli bireylerin evlilik kavramı ile ilgili toplam 100 adet ve 47 farklı metafor ürettikleri görülmüştür. Üretilen metaforların ortak özellikleri bağlamında 6 ayrı kavramsal kategori oluşturulmuştur. Katılımcıların oluşturdukları toplam 100 metaforun büyük kısmının olumlu anlam içerdiği görülmüştür. Bu bulgu araştırma kapsamındaki evli bireylerin evliliğe ilişkin algılarının çoğunlukla olumlu olduğunu göstermektedir. Türk kültüründe evlilik ve aile olgularına büyük önem verilir. Yapılan iki ayrı saha araştırmasında da (Yılmaz, 2006) katılımcıların oldukça büyük bir kısmı ailenin korunması gereken değerlerin başında geldiğini ve aile kurumunun haytalarında önemli bir yer teşkil ettiğini ifade etmişlerdir (Yıldırım ve Yıldırım, 2011). Benzer olarak, Bener ve Günay (2013)'ın üniversite öğrencilerinin evlilik ve aileye yönelik tutumlarının incelendiği araştırmada da gençlerin büyük kısmı bu kavramlara karşı olumlu tutumlar bildirmişlerdir. Aile ve Sosyal Politikalar Bakanlığı, 2014; Başbakanlık Aile ve Sosyal Araştırmalar Genel Müdürlüğü, 2008, 2009 ve TÜİK, 2011 verileri 
boşanma oranlarının en çok lise ve dengi okul mezunlarında olduğunu bildirmektedir. Bu araştırmaya katılan kişiler üniversite mezunu olan bireylerdir. Eğitim düzeyi yüksek olan kişilerde evlilik uyumunun yüksek ve boşanma oranlarının görece düşük olması; ağırlıklı olarak eğitim düzeyi yüksek olan kişilerin sorunlarını iletişim kurarak çözmeye çalışmalarına ve evliliklerini daha bilinçli ve özgür iradeleriyle yapmalarıyla açıklanmaktadır. Aktaş (2011) yürüttüğü araştırmasında, eğitim düzeyi yükseldikçe eşlerin evlilik ilişkisinde sorumluluk davranışlarını daha fazla sergilediklerini bildirmektedir. $\mathrm{Bu}$ veriler ve bilgiler, bir yandan bu araştırmadaki üniversite mezunu olan evli bireylerin evlilikle ilgili ağırlıkla olumlu bulunmuş olan algılarını destekler niteliktedir. Diğer yandan Çağ ve Yıldırım (2013) evlilik uyumu ve eğitim düzeyi arasında negatif bir ilişki bulmuşlar ve eğitim düzeyi arttıkça kişilerin evliliklerinden aldıkları doyumun azaldığını bildirmektedirler. Ulaşılan farklı bulgular, esasen bireylerin evliliğe ilişkin algılarında sadece eğitim düzeylerinin etkili olmadığını, algıların kaynağında başka değişkenlerin de etkili olduğunu düşündürmektedir.

Araştırmanın bir diğeri alt amacı olan, katılımcıların evliliğe dâir ürettikleri metaforların cinsiyetlerine göre nasıl olduğunu belirlemek için yapılan analiz sonuçlarına göre; bütün kategorilerde kadın katılımcıların erkek katılımcılara göre daha olumlu anlamlar barındıran metaforlar ürettikleri belirlenmiştir. Geliştirilen metaforlara genel olarak bakıldığında ise; kadınların oluşturdukları metaforların büyük kısımının olumlu, oldukça az bir kısımın olumsuz anlamlar içerdiği görülmüştür. Erkeklerin geliştirdikleri metaforların da yine olumlu yönde olanlarının olumsuz içerikte olanlardan, kadınlarınki kadar fark olmamakla beraber, daha fazla olduğu belirlenmiştir. Bütün bu bulgular her iki cinsiyetinde ağırlıklı olarak evliliğe ilişkin olumlu algılara sâhip olduklarını göstermekle beraber karşılaştırma yapıldığında, kadınların evliliğe ilişkin algılarının erkeklere göre daha olumlu olduğu görülmektedir. İlgili alanda doğrudan olmasa da dolaylı olarak benzer çalışma sonuçları mevcuttur. Yalçın (2014)'ün kadınlarla yürüttüğü çalışmasında kadınların \%53.3'ü evliliğini çok iyi-iyi olarak değerlendirirken \%18.3'ü evliliğini çok kötü-kötü olarak değerlendirmiş, \%28.1'i ise normal olarak değerlendirmiştir. Bener ve Günay (2013)'ın çalışmalarının bulguları da, kadınların evliliğe ilişkin olumlu tutumlarının erkeklerinkinden anlamlı düzeyde yüksek olduğunu göstermektedir. Polat (2006)'ın araştırmasında erkeklerin evlilikten aldıkları doyumun daha az ve buna bağlı aldatma 
eğilimlerinin kadınlarınkinden daha yüksek olduğu bildirilmektedir. Diğer bir araştırma da (Exline, Baumeister, Bushman, Campbell ve Finkel, 2004) kadınların evlilikte daha affedici olduklarını göstermektedir. Bütün bu bulgular kadınların evlilik ilişkisi içindeki algılarının erkeklerinkinden daha olumlu olduğunu doğrular niteliktedir. Ulaşılan çalışmaların büyük bir kısmının Türk kültürü içinde yürütülmüş olması bu sonucun kültürel bir boyutu olduğunu düşündürmektedir. Kültürümüzde "yuvayı dişi kuş yapar" deyişinde olduğu gibi kadından daha fazla fedakâr olması, anlayışlı olması, her koşulda yuvasına sahip çıkması gibi kültürel öğretilerin bu bulguda etkili olduğu ileri sürülebilir. Benzer şekilde, kültürümüzde kadından evlilikle ilgili ev içi işler, çocuk bakımı, evin çekip çevirilmesi, idare etme gibi sorumlulukların beklenmesi (Ersöz, 1999) kadının evliliğin sorumluluğunu üstlenme ve evlilikte çıkması muhtemel sorunları önleme gibi misyonlar edinmesine neden olabileceği düşünülmektedir. Dolayısıyla kadının evliliğini daha olumlu hale getirme çabaları evliliğe dair algısının olumlu yönde olmasını sağlayabilir.

Son olarak araştırmanın bir diğer alt amacı olan araştırma kapsamındaki bireylerin evlilik olgusuna dâir algılarının çocuk sâhibi olup olmama değişkenine göre nasıl olduğunu görebilmek için yapılan analiz sonuçlarına göre; bütün kategorilerde çocuk sâhibi olanların çocuk sâhibi olmayanlara göre daha fazla olumlu içerikte metaforlar ürettikleri görülmüştür. Genel olarak bakıldığında da; çocuğu olan katılımcıların oluşturdukları olumlu metaforların çocuk sâhibi olmayan katılımcıların geliştirdikleri olumlu metaforlardan oldukça fazla miktarda olduğu göze çarpmıştır. Elde edilen bu bulgular yine hem çocuğu olan hem olmayanların evliliğe ilişkin algılarının olumlu olduğunu göstermekle beraber, karşılaştırma yapildığında çocuğu olanların evlilikle ilgili algılarının daha olumlu olduğu göze çarpmaktadır. Alandaki çalışmalar bu bulguyu dolaylı olarak da olsa destekleyen bazı bulgular sunmaktadır. Türkaslan (2007) çocuk sayısına göre boşanma oranlarının, çocuksuz ailelerde yüksek olduğunu bildirmiş ve çocuk varlığının boşanmayı önleyen bir unsur olduğunu ileri sürmüştür. Yine Demirci ve diğerleri (2005) çocuksuz evliliklerde boşanma oranlarının yükssek olduğunu bildirmişlerdir. Başbakanlık Aile ve Sosyal Araştırmalar Genel Müdürlüğü (2009)'nün boşanma nedenleri araştırmasında da katılımcıların \%57.4'ü çocuk sâhibi olmanın boşanmayı engelleyici bir faktör olarak gördügü bildirilmiştir. Yine bütün bu bulgular, bu araştırmanın bulgularıyla tutarlılık 
göstermenin yanında bu sonuçlara ulaşmada da kültürel bir boyut olduğu düşünülmektedir. Ana-babalık rolü kültürümüzde oldukça önemsenen bir roldür ve bu rol kişilerin evlilik ve ailelerine sâhip çıkmalarında bir motivasyon kaynağı olarak düşünülmektedir. Dolayısıyla ebeveyn olan kişilerin evlilikle ilgili daha olumlu olan algılarında sâhip oldukları bu rolün etkisi olduğu söylenebilir.

$\mathrm{Bu}$ çalışmada üniversite mezunu olan kişilerin evliliğe ilişkin algılarının olumlu olduğu görülmüştür. Ancak bu nitel çalışmanın verileri genellenemez olarak düşünülür ve bir sinırlılık olarak ele alınacak olursa konuyu nicel ve daha geniş örneklemlerle ya da karma desen araştırmalarla yeniden incelemenin yararlı olacağı önerilebilir. Diğer yandan bu çalışmada yalnızca cinsiyet ve çocuk sâhibi olup olmama değişkenlerine odaklanılmıştır. $\mathrm{Bu}$ değişkenlere ek olarak evlilik algısını etkileyebilecek başka değişkenlerle yürütülecek çalışmaların alana katkı sağlayacağı düşünülmektedir. Ayrıca sosyolojik ve psikolojik yönleri ile insanı yakından ilgilendiren evlilik ve aile konularına dönük daha fazla bilimsel çalışmanın yapılması önerilebilir. Son olarak, okullarda rehberlik ve psikolojik danışmanlık faaliyetleri kapsamında yürütülen müşavirlik/konsültasyon hizmetlerinde, ailelere öncelikle çocuklarının ve kendilerinin ruh sağlıkları üzerinde evlilik ve aile hayatının önemine vurgu yapan çalışmalar planlanıp yürütülebilir.

\section{Kaynakça}

Aile ve Sosyal Politikalar Bakanlığı. (2014). Türkiye boşanma nedenleri araştırmast. Ankara.

http://ailetoplum.aile.gov.tr/data/54292ce0369dc32358ee2a46/tbna20 14_kitap.pdf.

Akıntürk, T. (1996). Aile hukuku (4. baskı). Ankara: Beta.

Aktaş, Ö. (2011). Boşanma nedenleri ve boşanma sonrasında karşılaşılan güçlükler. Yayımlanmamış yüksek lisans tezi, Dokuz Eylül Üniversitesi, Eğitim Bilimleri Enstitüsü.

Aydın, O. ve Baran, G. (2010). Toplumsal değişme sürecinde evlenme ve boşanma. Toplum ve sosyal hizmet dergisi, 21(2), 117-126.

Başbakanlık Aile ve Sosyal Araştırmalar Genel Müdürlüğü (2008). Boşanma nedenleri araştırması. Ankara. 
http://w3.gazi.edu.tr/ battal/kitaplar/bosanma_sebepleri.pdf.

Başbakanlık Aile ve Sosyal Araştırmalar Genel Müdürlüğü (2009). Boşanma nedenleri araştırması. Ankara.

http://ailetoplum.aile.gov.tr/data/54293ea2369dc32358ee2b25/kutuph ane_56_bosanma_nedenleri_arastirmasi.pdf.

Bener Ö. ve Günay, G. (2013). Gençlerin evlilik ve aile yaşamına ilişkin tutumlar1. Karabük Üniversitesi Sosyal Bilimler Enstitüsü Dergisi, $3(1), 1-16$.

Bilen, M. (1996). Sağlıklı insan ilişkileri, ailede/kurumlarda/toplumda. Ankara: An1.

Collins, E. C. ve Green J. L. (1990). Metaphors: the construction of a perspective. Theory into Practice, 29(2), 71-77.

Çağ, P. ve Yıldırım, İ. (2013). Evlilik doyumunu yordayan ilişkisel ve kişisel değişkenler. Türk Psikolojik Danışma ve Rehberlik Dergisi, 4(39), 13-23.

Çakır, B. (2011). Modernleşme sürecinde Türkiye'de evlilik kurumunun işleyişi ve boşanma eğilimlerinin seyri. Yayımlanmamış doktora tezi, İstanbul Üniversitesi, Sosyal Bilimler Enstitüsü.

Çokluk, Ö. (2015). Araştırma raporunun yazılması. R. Kumar, (Ed.), Araştırma yöntemleri - yeni başlayanlar için adım adım araştırma rehberi içinde (339-349). Ankara: Edge Akademi.

Demirci, Ş., Günaydın, İ, Doğan H. ve Aynacı Y. (2005). Konya ilindeki boşanmaların retrospektif değerlendirilmesi. Adli Tip Dergisi, 19(1), 22-28.

Erkal, M., E. (1997). Sosyoloji (8. bask1). İstanbul: Der.

Ersöz, A. G. (1999). Cinsiyet rollerine ilişskin beklenti, tutum, davranışlar ve eşler arası sorumluluk paylaşımı (Kamuda çalışan yönetici kadınlar örneği). Ankara: T.C Kültür Bakanlığı.

Exline, J. J., Baumeister, B. J., Bushman, B. J., Campbell, W. K. ve Finkel, E. J. (2004). Too proud to let go: Narsissistic entitlement as a barrier to forgiveness. Journal of Personality and Social Psychology, 87(6), 894-912. 
Güçlü, S. (1998, Mayıs). Türkiye'de aile araştırmaları, sorunlar, öncelikler ve çözüm önerileri. III. Aile Şurası Tebliğleri, Ankara.

Halford, W. K., Kelly, A. ve Markman, H. L. (1997). The concept of a healthy marriage. Clinical handbook of marriage and couple intervention. Chichester: Wiley Publishing.

Hansen, J. C. ve L'abate, L. (1982). The classification of normal families: functionality and dysfunctionality. Approaches to family therapy. New York: Macmillan Publishing Co. Inc.

Hojat, M., Shapurian, R., Foroughi, D., Nayerahmadi, H., Farzaneh, I. M., Shafieyan, M. ve Parsi, M. (2000). Gender differences in traditional attitudes toward marriage and the family: An empirical study of Iranian immigrants in the United States. Journal of Family Issues, 21(4), 419-434.

Hovardaoğlu, S. ve Binici-Azizoğlu, S. (1996). Evlilik için karşılaştırma düzeyi ölçeğinin (ekdö) geçerlik ve güvenirlik çalışması. Türk Psikoloji Dergisi, 11(38), 66-76.

Jacobson, N. S. ve Gurman, A. S. (1995). Clinical handbook of couple theory. New York: The Gilford.

Johnson, M. G. ve Malgady, R. G. (1979). Some cognitive aspects of figurative language: Association and metaphor. Journal of Psycholinguistic Research, 8(3), 249-265.

Kağıtçıbaşı, Ç. (1990). İnsan, aile, kültür. İstanbul: Remzi.

Kağıtçıbaşı, Ç. (2007). Kültürel psikoloji. Kültür bağlamında insan ve aile. İstanbul: Evrim.

Kammeyer, K. C. W. (1990). Marriage and family: a foundation for personal decisions. Boston: Allyn and Bacon.

Karataş, Z. (2002). Anne baba saldırganlı̆̆ ile lise öğrencilerinin saldırganlığ arasındaki ilişkinin incelenmesi. Yayımlanmamış yüksek lisans tezi, Çukurova Üniversitesi, Sosyal Bilimler Enstitüsü.

Krippendorff, K. (1993). Major metaphors of communication and some constructivist reflections on their use. Cybernetics \& Human Knowing, 2(1), 3-25. 
Lakoff, G. ve Johnson, M. (2007). Metaforlar: Hayat, anlam ve dil (G. Y. Demir, Çev.). Ankara: Paradigma. (Orijinal çalışma basım tarihi 2003)

Merriam, S. B. (2015). Nitel araştırma. Desen ve uygulama için rehber. (S. Turan, Çev. Ed.). Ankara: Nobel. (Orijinal çalışma basım tarihi 2015)

Miles, M. B. ve Huberman, A. M. (1994). An expanded sourcebook qualitative data analysis. California: Sage Publications.

Nazlı, S. (2014). Aile danışmanlı̆ğ (11. baskı). Ankara: Anı.

Ozankaya, Ö. (1979). Toplum bilimine giriş. Ankara Üniversitesi, Siyasal Bilimler Fakültesi Yay. No:431.

Öngider, N. (2013). Boşanmanın çocuk üzerindeki etkileri. Psikiyatride Güncel Yaklaşımlar, 5(2), 140-161.

Özabacı, N. ve Erkan, Z. (2014). Aile danışmanlığı. Kuram ve uygulamalara genel bir bakış. Ankara: Pegem.

Özgüven, İ. E. (2001). Kişiler arası iletişim. Ailede iletişim ve yaşam. Ankara: PDREM.

Polat, D. (2006). Evli bireylerin evlilik uyumlarl, aldatma eğilimleri ve çatışma eğilimleri arasındaki ilişsilerin bazı değişkenler açısından incelenmesi. Yayımlanmamış yüksek lisans tezi. Ankara Üniversitesi, Sosyal Bilimler Enstitüsü.

Punch, K. F. (2011). Sosyal araştırmalara giriş. Nicel ve nitel yaklaşımlar. (Z. Etöz, Çev. Ed.). Ankara: Siyasal. (Orijinal çalışma basım tarihi 2010)

Sabatelli, R. M. (1984). The marital comparation level index: A measure for assessing outcomes relative to expectation. Journal of Marriage and the Family, 46(3), 651-662.

Saxton. L. (1982). Marriage. The nature of marriage, the individual, marriage, and the family. California: Wadsworth Publishing.

Şahinkaya, R. (1975). Psiko-sosyal yönleriyle aile. Ankara: Kardeş

Şentürk-Pehlivan, K. (2004). Kadın psikiyatrik hastaların cinsel yaşam, evlilik, aile planlaması ve kontrasepsiyon, gebelik ve çocuk sahibi olma, aids ve cinsel yolla bulaşan hastalıklar açısından riskli dav- 
ranışlarının genel populasyonla karşılaştırmalı çalışması. Uzmanlık tezi, Bakırköy Mazhar Osman Ruh sağlığı ve Sinir Hastalıkları Eğitim ve Araştırma Hastanesi.

Şirvanl1-Özen, D. (1998). Eşlerarası çatı̧̧ma ve boşanmanın farklı yaş ve cinsiyetteki çocukların davranış ve uyum problemleri ile algıladıkları sosyal destek üzerindeki rolü. Yayımlanmamış doktora tezi, Hacettepe Üniversitesi, Sosyal Bilimler Ensititüsü.

Tatlılıoğlu, K. ve Demirel, N. (2016). Sosyal bir gerçeklik olarak boşanma olgusu: Sosyal psikolojik bir değerlendirme. Akademik Sosyal Araştırmalar Dergisi, 4(22), 59-73.

Turhan, M. (2015). Kültür değişmeleri. Sosyal psikoloji bakımından bir tetkik. Ankara: Altınordu.

Türkiye İstatistik Kurumu (2011). Evlenme ve boşanma istatistikleri. tuik.gov.tr adresinden edinilmiştir.

Türkaslan, N. (2007). Boşanmanın çocuklar üzerine olumsuz etkileri ve bunlarla başetme yollar1. Aile ve Toplum Dergisi, 9(3), 99-108.

Uzun, Ç. (2013). Anne-babası boşanmış ve boşanmamış çocuklarda depresyon ve sosyal becerilerin değerlendirilmesi. Yayımlanmamış yüksek lisans tezi, İstanbul Arel Üniversitesi, Sosyal Bilimler Enstitüsü.

Ünal, V. (2013). Geleneksel geniş aileden çekirdek aileye geçiş sürecinde boşanma sorunu ve din. Uluslararası Sosyal Araştırmalar Dergisi, 6(26), 588-602.

Williams, K. (2003). Has the future of marriage arrived? A contemporary examination of gender, marriage and psychological well-being. Journal of Health and Social Behavior, 44, 470-487.

Yalçın, H. (2014). Evlilik uyumu ile sosyodemografik özellikler arasındaki ilişki. Eğitim ve Öğretim Araştırmaları Dergisi, 3(1), 250-261.

Yalçın, İ. ve Hamamcı, Z. (2012). Evlilik öncesi psikolojik danışma. Ankara: An1.

Yavuz, A. E. (2003). Tutuklu ya da hükümlü erkek ergenlerde kriminolojik öykü ile madde kullanımı ve aile yapısı arasındaki ilişki. 
Yayımlanmamış yüksek lisans tezi, İstanbul Üniversitesi, Adli Tıp Enstitüsü.

Yıldırım, A. ve Şimşek, H. (2008). Sosyal bilimlerde nitel araştırma yöntemleri. Ankara: Seçkin.

Yıldırım, E. ve Yıldırım, E. (2011). Aile içi ilişkiler ve iletişim. K. Canatan ve E. Y1ldırım, (Ed.), Aile sosyolojisi içinde (139-153). İstanbul: Açılım.

Yılmaz, T. (2006). Üniversiteli bile ‘Töre için öldürürüm’ derse. http://arama.hurriyet.com.tr/arsivnews.aspx $? \mathrm{id}=5325137$. 